\title{
THE INFLUENCE OF CHROMIUM COMPOUNDS ON YEAST PHYSIOLOGY*
}

\author{
(A REVIEW) \\ P. RASPOR ${ }^{1}$, M. BATIČ ${ }^{1}$, POLONA JAMNIK ${ }^{1}$, DJ. JOSIĆ ${ }^{2}$, RADMILA MILAČIČ $\check{C}^{3}$, MAJA PAŠ $\check{S}^{1}$, \\ MARJETA RECEK ${ }^{3}$, VESNA REŽIĆ-DEREANI ${ }^{3}$, MIHAELA SKRT ${ }^{1}$ \\ ${ }^{1}$ Food Science and Technology Department, Biotechnical Faculty, University of Ljubljana, \\ Jamnikarjeva 101, 1000 Ljubljana, Slovenia, ${ }^{2}$ Octapharma, Vienna, Austria, ${ }^{3}$ Institut Jožef Stefan, \\ Ljubljana, Slovenia
}

(Received: 1 September 1999; accepted: 15 September 1999)

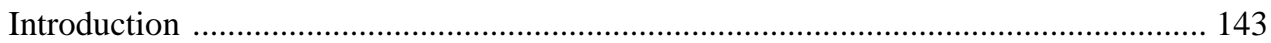

Chromium as an ion of choice for yeast metabolism ................................................... 146

Chromium accumulation in yeasts biomass ............................................................ 149

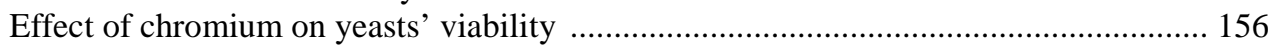

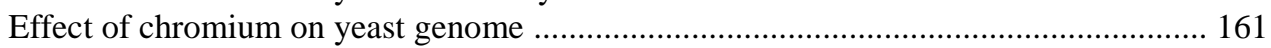

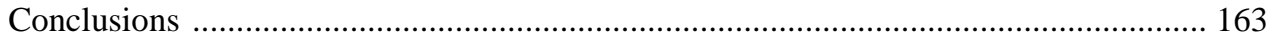

Keywords: chromium, yeasts physiology

\section{Introduction}

Metal ions and yeasts metabolism was reviewed quite a few times in the last decades by eminent researchers [1-4]. In spite of this excellent work in the past it is clear that metal ions nutrition in yeasts is still open for further research. After specifying requirements and functions of macroelements in yeasts $[4,5]$ the era of trace

*This publication is based on the inaugural lecture by the author as an honorary member of the Hungarian Society for Microbiology held at the 13th International Congress of the Hungarian Society for Microbiology, August 28 - September 1, 1999, Budapest, Hungary 
elements [6] started and in the recent years one can see many publications considering the problem of trace elements, which seems to be really needed for efficient metabolism. It seems that new analytical approaches [7] busted new wave of research (i.e. NMR, EPR, Raman spectroscopy) into the field of ionic nutrition, which was already in the focus some years ago $[6,8,9]$.

The problem of ionic nutrition is also strongly oriented to the human diet. Regarding this topic there are profound reviews available [10,11] and some of them specially emphasize chromium [12, 13, 15], since it became important through revealing its function in glucose tolerance factor (GTF). Consequently, all the results from studies of ionic nutrition in microbes are oriented towards metabolism of higher organisms and finally to human diet $[16,17]$. It is evident that nutrition of human is becoming one of the major fields of research [18] with laying stress on understanding metabolism [19], defining standards of mineral intake [20] and creating functional foods $[21,22]$.

In the environmental field one can see significance of metal ions in two directions: the pollution control and mining technology. The removal or uptake of metal is concerned with the increasing value of some metals on one hand, and with awareness for ecological effect of toxic metals released into the environment on the other [3, 23-26]. In the area of environmental care the conventional methods for removing metals from polluted streams or ore processing solutions can include traditional chemical and physical processes which can be ineffective or extremely expensive, especially when metals are present in low concentrations from 1 to 100 $\mu \mathrm{g} / \mathrm{mL}[27,28]$. In addition, the history of the waste (source and its pretreatments) seems to play an important role for selecting proper microbial biomass for biosorption with a goal of bioremediation. In some cases it was proved that although the yeast biomass was capable of removing more than $99 \%$ chromium from electroplating wastewater, it was only capable of removing 50-60\% of chromium from tannery wastewater [29].

Regarding environment we should be very careful since everything what was released into soil, water or air from technological activities comes back to food chains and consequently - directly or indirectly - to human diet [30]. The link to environmental biochemistry of chromium is evident [31] what is crucial for tracing chromium flux in environmental niches and understanding oxidation-reduction dynamics in chemical [32, 33] as well as in biological world [34].

Moreover, successful ionic nutrition is related to the metal uptake, which is understood as biosorption and bioaccumulation and is important for all living creatures. Selective advantages are confirmed for species which are capable of uptake and retaining ions (from metal or transition elements) available in limited amounts in 
surroundings. During the last decades the trace elements such as $\mathrm{Mn}, \mathrm{Fe}, \mathrm{Co}, \mathrm{Ni}, \mathrm{Zn}, \mathrm{V}$ and $\mathrm{Cr}$, were found to be essential or at least beneficial for normal metabolism in all organisms [35].

The metal uptake starts with fast biosorption on the cell wall and then continues with slower bioaccumulation. Bioaccumulation mechanisms consist of metal ion translocation through the cell membrane into the cell and its deposition in adequate store compartment in living cell. In principle, all the steps mentioned are metabolically dependent, what is not the case in metabolically independent passive processes, which are based on different mechanisms for metal sequestering onto the cell surface. Biosorption is strongly affected by combination of other metal ions in cell surroundings [36]. This uptake is metabolically independent but depends on the chemical make-up of the cell wall of particular species. Enormous diversity among yeasts has been found by various approaches of studying yeast cell envelope [37]. Consequently, the metal type, its ionic form in particular solution, and structure of on active binding site responsible for sequestering the metals are factors which should be included into the predicted model when influence on biosorption is concerned. It depends on the degree of affinity between different types of metal species or its ionic forms and the target site at the cell wall molecular structure [38]. Additionally, competition of other ions should not be ignored since there are some observations showing competition effects (i.e. in cadmium/iron system) [39].

Bioaccumulation is generally defined as active mode of metal uptake by living cells [3] and depends on its metabolic activity. Bioaccumulation process can be significantly affected by the presence of metal ions, which are accumulated. Additionally, the tolerance of yeast to the environmental concentration of metal ion is crucial for conducting bioaccumulation. Consequently, yeast ability to control the intracellular concentration of the ion in the range, which is not toxic for metabolic processes, have to be maintained for efficient bioaccumulation.

When a selection of suitable microorganism for metal bioaccumulation is in consideration, the yeasts showed to be advantageous among the microbial candidates, as they have been known to serve human needs for a long time. They can be exploited in metal removing processes from industrial wastes [40], as well as for human and animal nutrition since they belong to microbes which are traditionally recognized as safe [41]. However, the status of safe yeast is dominantly adopted for Saccharomyces cerevisiae, which is the common species present in food and feed production as well as in human and animal diet.

Nutrition has been very important in the last years in human and animal diet [11]. Mineral nutrition is one of the key issues in functional foods [21]. As an example of food mineral nutrition chromium can be selected. The chromium function as the key 
element in glucose tolerance factor has been studied from different perspectives since 1957 [42]. In respect to chromium metabolism and function there are still many nonclarified situations, which additionally stimulate research in bioaccumulation. Majority of publications claims that it is an essential element for glucose and fat metabolism in mammals [12, 14, 16, 43-45]. There are not many informations about chromium tolerance, ionic nutrition [46], transport [2], biosorption [47, 48] and bioaccumulation in yeasts [49-51]. The natural chromium content in Saccharomyces cerevisiae is less than $0.07 \mu \mathrm{g} / \mathrm{g}$ dry mass [49], when its availability depends on natural substrates for growth. It is claimed that its structural function is the stabilization of the tertiary structure of proteins or nucleic acids on one hand and the metabolic function in glucose metabolism in mammals $[12,14]$ and yeasts [52-54] on the other hand.

\section{Chromium as an ion of choice for yeast metabolism}

Chromium is included on the list of essential trace elements for humans and some animals [45] and expresses at least beneficial effect in other living species tested including yeasts [52]. Depending on its form it can be toxic and even cancerogenic [55, 56].

Chromium belongs to the first series of transition metals. Its position in subgroup VI B of the periodic system is surrounded by three elements with a known biological function, like vanadium, manganese, and molybdenum. Chromium can occur in every oxidation state from $2-$ to $6+$, but the most commonly found are $0,3+$, and $6+$ [34]. The 2+ state does not exist in the biological system [12, 14, 44]. Tetravalent and pentavalent chromium oxidation states are rare and unstable, like divalent chromium. However, the electron precession resonance (EPR) spectroscopy has shown stabilization of the pentavalent complexes, formed via the reduction of hexavalent chromium with various biological thiols prior to DNA binding [57]. The hexavalent form is almost always linked to oxygen, and forms chromate $\left(\mathrm{CrO}_{4}{ }^{2-}\right)$ or dichromate $\left(\mathrm{Cr}_{2} \mathrm{O}_{7}{ }^{2-}\right)$ ions, which are strong oxidants. The hexavalent chromium compounds demonstrate acidic properties and their colors range from yellow to orange [12, 14, 57]. This ionic complex has negative charge what makes it very suitable for transport by sulfate transporters into the cell. These ions are easily reduced to $\mathrm{Cr}$ (III) in acidic environment. Additionally, the presence of reductants in the surrounding has been proved to be of extreme importance. In this regard, the case of iron(II) can serve as demonstration of appropriate reductant efficiency [58]. In some yeasts and various fungi, though not Saccharomyces cerevisiae, special metal-siderophore interaction occurs (Rhodotorula - rhodotorulic acid siderophores) [59-61], which has the function 
to promote bioaccumulation of particular ions. Originally, siderophores are chelating agents excreted by many microorganisms to facilitate the uptake of ferric ions [61]. However, there is some evidence that chromium(III) can also be inserted into siderophores. Resulting $\mathrm{Cr}(\mathrm{III})$-siderophore complexes are kinetically inert (i.e. ligand exchange is slow) [60].

The trivalent state of chromium is thermodynamically the most stable and is commonly found in the living systems. Trivalent chromium has a strong tendency to form co-ordination compounds, complexes and chelates. Its co-ordination number is 6 , and it can bind ligands to form hexaco-ordinate or octahedral complexes. Consequently, this ionic complex has positive charge what makes it less suitable for transport into the cell. Free chromic ions do not exist in aqueous solutions. They are always co-ordinated, either with water or with other ligands in the solution. Metalligand bonds may involve oxygen, nitrogen or sulfur [12, 14, 44, 57, 62].

At neutral or basic $\mathrm{pH}, \mathrm{Cr}-\mathrm{H}_{2} \mathrm{O}$ bonds are modified and $\mathrm{Cr}-\mathrm{OH}^{-}$bonds are created, leading to the formation of giant macromolecules (polymerization of hydrated $\mathrm{Cr}-$ known as olation) that precipitate and are thus biologically inert. Oxalate ions and other strong ligands can prevent and reverse olation, while weaker ligands like pyrophosphate, methionine, serine, glycine, leucine, lysine and proline prevent the reaction at physiological $\mathrm{pH}$, what enables functioning of chromium in cell metabolism $[12,14,57]$.

Following the message of Mertz [12], the most important oxidation state of chromium in biological systems is $3+$ and is therefore not likely to participate in oxidation/reduction reactions. Furthermore, chromium(III) occurs mostly in octahedral configuration with coordination number 6 and its relative inertness of the chromiumligand bond makes it suitable for structural function, like the stabilization of tertiary structures in proteins or nucleic acids.

The yeast tolerance to metal ions is key parameter in the conditions when yeasts are grown in media loaded with heavy metals. The variation in tolerance or resistance among yeast species can be the result of different cell wall compositions [35]. There is neither much data about the microbial requirements for chromium nor available data for chromium biosorption and bioaccumulation. Frequently it is regarded as a toxic element to which some microorganisms have evolved resistance mechanisms [64].

Most common sites of chromium binding in yeasts are in the cell walls and cell membrane structure. In yeast cell the compounds such as pyrophosphate, polysaccharides, proteins, amino acids (Table I) are potential donors of ligand donor groups $[12,27,35,38,65]$. They act as ligand donor groups through oxygen, nitrogen and sulfur [66]. 
Table I

Amino acids with metal-binding groups in protein [adapted from 38, 60, 63]

\begin{tabular}{|c|c|c|c|}
\hline Amino acid & Side chain & Character & Metals-binding \\
\hline Alanine & $-\mathrm{CH}_{3}$ & Neutral & I \\
\hline Arginine & $-\mathrm{CH}_{2} \mathrm{CH}_{2} \mathrm{CH}_{2} \mathrm{NHC}\left(\mathrm{NH}_{2}^{+}\right)\left(\mathrm{NH}_{2}\right)$ & Basic & $*$ \\
\hline Asparagine & $-\mathrm{CH}_{2} \mathrm{CONH}_{2}$ & Neutral & $\mathrm{Ca}$ \\
\hline Aspartic acid & $-\mathrm{CH}_{2} \mathrm{COOH}$ & Acidic & $\mathrm{Ca}, \mathrm{Zn}, \mathrm{Fe}, \mathrm{M}(\mathrm{II}), \mathrm{M}(\mathrm{III})$ \\
\hline Cysteine & $-\mathrm{CH}_{2} \mathrm{SH}$ & Neutral & $\mathrm{Zn}, \mathrm{Cu}, \mathrm{Fe}, \mathrm{Ni}, \mathrm{Mo}$ \\
\hline Glutamic acid & $-\mathrm{CH}_{2} \mathrm{CH}_{2} \mathrm{COOH}$ & Acidic & $\mathrm{Ca}, \mathrm{Zn}, \mathrm{Fe}, \mathrm{M}(\mathrm{II})$ \\
\hline Glutamine & $-\mathrm{CH}_{2} \mathrm{CH}_{2} \mathrm{CONH}_{2}$ & Neutral & $\mathrm{Fe}$ \\
\hline Glycine & $-\mathrm{H}$ & $\begin{array}{c}\text { Nonpolar } \\
\text { Hydrophobic }\end{array}$ & $\mathrm{Cr}$ \\
\hline Histidine & $-\mathrm{CH}_{2} \mathrm{C}_{3} \mathrm{H}_{3} \mathrm{~N}\left(\mathrm{NH}^{+}\right)$ & $\begin{array}{c}\text { Neutral } \\
\text { Basic }\end{array}$ & $\underset{*}{\mathrm{Zn}, \mathrm{Cu}, \mathrm{Mn}, \mathrm{Fe}, \mathrm{Ni}}$ \\
\hline Isoleucine & $-\mathrm{CH}\left(\mathrm{CH}_{3}\right) \mathrm{CH}_{2} \mathrm{CH}_{3}$ & $\begin{array}{c}\text { Nonpolar } \\
\text { Hydrophobic }\end{array}$ & I \\
\hline Leucine & $-\mathrm{CH}_{2} \mathrm{CH}\left(\mathrm{CH}_{3}\right)\left(\mathrm{CH}_{3}\right)$ & $\begin{array}{c}\text { Nonpolar } \\
\text { Hydophobic }\end{array}$ & $\mathrm{Cr}$ \\
\hline Lysine & $-\mathrm{CH}_{2} \mathrm{CH}_{2} \mathrm{CH}_{2} \mathrm{CH}_{2} \mathrm{NH}_{3}^{+}$ & Basic & $*, \mathrm{Cr}$ \\
\hline Methionine & $-\mathrm{CH}_{2} \mathrm{CH}_{2} \mathrm{SCH}_{3}$ & $\begin{array}{c}\text { Nonpolar } \\
\text { Hydrophobic }\end{array}$ & $\mathrm{Cu}, \mathrm{Fe}, \mathrm{Cr}$ \\
\hline Phenylalanine & $-\mathrm{CH}_{2} \mathrm{C}_{6} \mathrm{H}_{6}$ & $\begin{array}{c}\text { Nonpolar } \\
\text { Hydrophobic }\end{array}$ & I \\
\hline Proline & $-\mathrm{CH}_{2} \mathrm{CH}_{2} \mathrm{CH}_{2} \mathrm{NH}_{2}^{+}$ & $\begin{array}{c}\text { Nonpolar } \\
\text { Hydrophobic }\end{array}$ & $\mathrm{Cr}$ \\
\hline Serine & $-\mathrm{CH}_{2} \mathrm{OH}$ & Neutral & $\mathrm{Ca}, \mathrm{Cr}, \mathrm{M}(\mathrm{I}) ?$ \\
\hline Threonine & $-\mathrm{CH}(\mathrm{OH}] \mathrm{CH}_{3}$ & Neutral & $\mathrm{Ca}, \mathrm{M}(\mathrm{I}) ?$ \\
\hline Tryptophan & $-\mathrm{CH}_{2} \mathrm{C}=\mathrm{CH}(\mathrm{NH}) \mathrm{C}_{6} \mathrm{H}_{4}$ & $\begin{array}{c}\text { Nonpolar } \\
\text { Hydrophobic }\end{array}$ & / \\
\hline Tyrosine & $-\mathrm{CH}_{2} \mathrm{C}_{6} \mathrm{H}_{4} \mathrm{OH}$ & Neutral & $\mathrm{Zn}, \mathrm{Fe}, \mathrm{Mn}, \mathrm{M}(\mathrm{III}), \mathrm{Ca}$ \\
\hline Valine & $-\mathrm{CH}\left(\mathrm{CH}_{3}\right)\left(\mathrm{CH}_{3}\right)$ & $\begin{array}{c}\text { Nonpolar } \\
\text { Hydrophobic }\end{array}$ & I \\
\hline$\gamma$-carboxyglutamic acid & $-\mathrm{CH}_{2} \mathrm{CH}(\mathrm{COOH})_{2}$ & & $\mathrm{Ca}$ \\
\hline$\beta$-hydroxyaspartic acid & $-\mathrm{CH}(\mathrm{COOH})(\mathrm{OH})$ & & $\mathrm{Ca}$ \\
\hline
\end{tabular}

Additionally, it was found in higher organisms that chromium can act as a substitute for magnesium ( $\mathrm{Mg}(\mathrm{II})$ ) in protein (enzyme) sites [38]. It is well known that many ions can interfere with each other [34]. In the case of chromium the action of nickel $(\mathrm{Ni}(\mathrm{II}))$ can be compared with chromium action because their co-ordination chemistry tends to be the same, both prefer octahedral co-ordination, and aluminium 
(Al(III)) which, like chromium, has a slow rate of ligand exchange and molybdenum (Mo(III)) with a range of octahedral complexes, which resemble compounds of $\mathrm{Cr}(\mathrm{III})$ [38].

Regarding chromium as an ion of choice for yeast metabolism, from the mentioned information one could expect that there might be some important activities still to be elucidated.

\section{Chromium accumulation in yeast biomass}

Already in 1978 it was noticed that the yeast $S$. carlbergensis was able to uptake chromium from the medium with $\left({ }^{51} \mathrm{Cr}\right.$-labelled) chromium chloride. The $5 \%(\mathrm{w} / \mathrm{v})$ glucose supplement increased the uptake of chromium into the yeast cell. Further glucose feeding to the growth media during cultivation did not improve chromium chloride uptake [67]. Their comments that diffusion is the only transport system into the cell have not been discussed since then. They based their conclusion on repeating glucose feeding. Much later it was reported that chromium(III) has to be organically bounded to be able to pass through the cell membrane [32]. Final explanation is still needed. For chromium(VI) it is claimed to use sulfate and phosphate transport route. Sulfate transporter has a function to translocate chromium(VI) as chromate $\left(\mathrm{CrO}_{4}{ }^{2-}\right)$ through the membrane into the cell because sulfate space conformation is very similar to chromate [68, 69]. Since first isolation of cDNA encoding High affinity sulfate transporter [70] there were published also other genes involved in transporting sulfate as well as chromate [71].

The complex structure of yeast envelope [37] protects vital processes in the cell. Chromium ion has to pass different barriers, the cell wall and membrane from the environment to the cell interior [72]. In the translocation process of metal ions into the yeast cell values for $\mathrm{pH}$, temperature, metal's biological availability, etc. should be considered as the most important environmental parameters. When the intracellular metal ion concentration rises to the critical level, it can interfere with vital processes resulting in cell death in the mechanism of metal ion translocation $[2,73]$.

The metal ions uptake is essentially a biphasic process consisting of a metabolism-independent and a metabolism-dependent step. The initial biosorption step for metal ions is rapid [74, 75], typically only a few minutes in duration [76], and is independent of temperature [77]. In the case of chromium it was found a correlation in yeast $S$. cerevisiae between $\mathrm{pH}$ and chromium(III) uptake at different starting $\mathrm{pH}$ values. The studied $\mathrm{pH}$ range from 2 to 6 showed chromium uptake up to $1.54 \mu \mathrm{mol} / \mathrm{g}$ dry biomass which was conducted at $28{ }^{\circ} \mathrm{C}$ for 4 hours in gently mixing conditions 
(200 rpm) [78]. Under the applied experimental conditions the cell surface deposition capacity for chromium (CSDC-Cr) of the yeast cells increased with the $\mathrm{pH}$. The initial binding step is thought to involve the microbial cell surface structure (e.g. cell wall components - polysaccharides). This agreed with the observation for other metal ions in the same $\mathrm{pH}$ range [79]. Complex growth media reduce bioavailability of the chromium(III) ion for yeast metabolism. $\mathrm{pH}$ value around 6 additionally enhances the problem of olation mentioned earlier. To avoid the problem of chromium(III) olation in complex aqueous media the $\mathrm{pH} 4$ was found to be suitable for yeast cultivation [80].

Fig. 1. Impact of chromium supplementation ( $5 \mathrm{mM} \mathrm{Cr}$ (III))in two different phases of bioprocess (at the beginning and in the exponential phase) on its uptake in aerobic cultivation of Candida intermedia ZIM 156 (82) 
In the absence of the metabolic activity non-viable biomass can still sequester metal ions from surroundings by biosorption [74, 77]. Chromium biosorption capacity of non-viable yeast biomass (heat inactivated) compared to viable counterpart from the same source was 2.5-fold higher [81] what is in favour of technological application in environmental technology (i.e. removing chromium from water streams) when low concentration of metal ion is to be eliminated.

When metal/biomass ratio was below $0.1 \mu \mathrm{mol} / \mathrm{g}$ dry mass Brady and Duncan [75] claimed that metal ion uptake to biomass was dependent on biosorption. $S$. cerevisiae, when glucose was added to the system where biomass and chromium were in the suspension, reached the ratio $0.577 \mu \mathrm{mol}$ of chromium per $\mathrm{g}$ dry yeast biomass, what indicates synchronous biosorption and bioaccumulation. Consequently, in viable yeast biomass chromium uptake was enhanced up to 5-fold [80, 81].

Studying chromium uptake in yeast, biosorption is not of primary importance over bioaccumulation, because chromium enriched biomass by cultivation was found more suitable for food and feed consumption.

If one takes into account mechanism for metal bioaccumulation [9], then active transport indicated is in response to electrochemical proton gradients, generated by membrane-bound $\mathrm{H}^{+}$-ATPases, across the cytoplasmic and vacuolar membranes. Experimental results suggested the involvement of metabolic activity in chromium(III) ion bioaccumulation. Namely, concentrations of chromium ions higher than $2.40 \mathrm{mM}$ stimulated a more intensive extrusion of $\mathrm{H}^{+}$ions from yeasts and glucose even enhanced the proton export out of the cell [80]. Additionally, it was found that some heavy metals can release other cations from the cell (i.e. $\mathrm{K}(\mathrm{I}), \mathrm{Mg}(\mathrm{II})$ ). This was observed by exposure of yeast cells to copper [79] but is no data for chromium available.

However, there is no other information whether known metal uptake systems have the capacity to transport chromium(III) ions or whether specific chromium ion transport into the cell even exists. Appropriate timing for chromium supplementation into growth media at different yeast growth phases was proved to be important for chromium bioaccumulation. The results showed that yeasts growth at higher chromium concentration added $(10 \mathrm{mM})$ at the beginning of the bioprocess was more inhibited but chromium(III) uptake into yeast biomass was higher.

Addition of chromium in the middle of the exponential growth phase had no notably effect on yeasts' growth but resulted in approximately 30\% lower chromium uptake. Cultivation of yeast $C$. intermedia ZIM 156 in $10 \mathrm{mM}$ chromium(III) doubled ( $2400 \mu \mathrm{g} / \mathrm{g}$ dry mass) its uptake in comparison to $5 \mathrm{mM}$ concentration in the medium [82]. Similar experiment with $C$. utilis showed growth inhibition at lower concentration [50]. 
Fig. 2. Concentration of chromium in biomass of Candida intermedia ZIM 156 in batch and combined batch/fed-batch culture in medium supplemented with chromium(III) $\left(100 \mu \mathrm{M} \mathrm{KCr}\left(\mathrm{SO}_{4}\right)_{2} \cdot 12 \mathrm{H}_{2} \mathrm{O}\right)$ after 20 hours cultivation (Total chromium (A) and organically bounded chromium (B)) [51]

Yeast growth and chromium bioaccumulation in biomass was studied in batch, fed-batch and continuous culture. Regarding chromium effects on biomass production, the batch cultivation mode was found to be better than combined batch/fed-batch. According to Kosman [83] this can be attributed to biosorption capacity of yeast biomass and better uptake of chromium in the beginning of the exponential growth 
phase. Such behaviour favors batch over combined batch/fed-batch operating mode in bioaccumulation of chromium(III) [78].

Consequently, total chromium accumulation in batch cultivation was 4.5 -fold higher compared to combined batch/fed-batch cultivation mode with yeast $C$. intermedia ZIM 156 [78]. On the contrary, combined batch/fed-batch cultivation mode was found to be beneficial over batch biomass production because of high concentration of organically bounded chromium in yeast biomass and technologically suitable specific growth rate $\left(\mu_{\max }=0.26 \mathrm{~h}^{-1}\right)$.

The high efficiency of this bioconversion can be seen through total vs. organically bounded chromium ratio in yeast biomass of $C$. intermedia ZIM 156 (Fig. 2) [51]. The organically bounded chromium is considered to be the fraction, which can be extracted from total yeast biomass with $\mathrm{NH}_{4} \mathrm{OH}$ [84].

When combined batch/fed-batch cultivation mode is analyzed, yeast $C$. intermedia ZIM 156 was found to be capable of chromium bioconversion into organically bounded chromium fraction as high as $60 \%$. Combined batch/fed-batch cultivation mode showed a 9-fold better chromium ratio in spite of a $22 \%$ lower total chromium concentration in yeast biomass.

On the other hand $C$. intermedia ZIM 156 cultivated in batch culture was able to bioconvert 12\%, when compared to yeast $S$. cerevisiae ZIM 198 cultivated in the same conditions which was able to convert $23 \%$ of chromium which came into the cell into organically bounded fraction. The fraction of organically bounded chromium (org. $\mathrm{Cr} /$ tot. $\mathrm{Cr}$ ) remained constant $(6 \%)$ in yeast biomass when supplementation with chromium(III) cross $1.44 \mathrm{mM}$. In bioprocess with $0.96 \mathrm{mM}$ chromium(III) Saccharomyces cerevisiae was metabolically capable to incorporate 3.9-fold higher portion of chromium into organically bounded fraction what had a consequence in chromium concentration factor (CCF) in yeast biomass which attained 236-fold higher value than in yeast biomass from control media (without chromium(III) supplementation).

The highest intracellular chromium binding capacity was found in S. cerevisiae for organic fractions in the molecular weight range from 10,000 to 100,000 and more $[78,80]$. Under normal conditions (no addition of chromium to growth media) chromium distribution was observed in a range of molecular weights between 10,000 and 3000 (Fig. 3). Many cytoplasmic biomolecules have the ability to bind metal ions. The diversity of intracellular organelles provides a wide range of potential binding sites $[38,63,85]$. 
Fig. 3. Chromium organically bounded incorporation factor of different molecular weight fractions of yeast $S$. cerevisiae grown in continuous culture with $28 \mu \mathrm{M}$ of glucose at dilution rate $0.08 \mathrm{~h}^{-1}$ in medium loaded with $96 \mu \mathrm{M}$ of chromium [80]

Regarding chasing chromium distribution among biomolecules similar results were obtained in biomass of yeast $C$. intermedia isolated as intracellular lowmolecular-weight chromium-binding biomolecules [86]. Determination of chromium in cell fractions of biomass collected during cultivation in chromium enriched medium revealed that it was present in all collected chromatographic peaks, however, chromium was unevenly distributed. The comparison of low molecular weight fractions in chromium enriched biomass with control sample showed remarkable difference in chromium distribution and its loading. Fractions with highest chromium concentrations were found in molecular weight range from 1500 to 7000. Two distinguishable peaks in this range contained the highest amount of chromium [86].

Binding sites of chromium, compartmentalization, localization in the cell and finally incorporation processes into yeast biomass are rather complex processes and many details remain to be elucidated. On practical scale we gained some experience to push yeast to accumulate chromium. There are many patents claiming efficiency of 
their bioprocessing strategy for yeast biomass enrichment with chromium [87-91] and just few publications [49, 50, 92], what confirm strong economical interest for this product in the future. This is not unusual since yeast biomass enriched with chromium is a source of GTF molecule (glucose tolerance factor) [42, 52, 93-96]. GTF molecule is actually a Cr-binding molecule, which influences glucose metabolism in humans. Some authors claim that GTF activity is correlated with the amount of chromium accumulated in yeast [97] but so far this observation is not clearly proved. Moreover, GTF function in yeast metabolism seems to be important, since there are experiments showing that GTF enhances glucose consumption also in yeast metabolism when added to the growth medium $[98,99]$.

However, its structure remains to be discovered in spite of many attempts in the past [54, 100-106]. The challenge of GTF is still not completely elucidated with its function in glucose and lipid metabolism [107, 108], in particularly to actual active substance in its molecule [54, 100-104] and with regards to its mechanism [106, 109111].

Due to the importance of GTF product there have been some attempts to make GTF biosubstitutes as already mentioned [112].

Table II

Chromium concentration in yeast biomass [113, 114]

\begin{tabular}{lc}
\hline Yeast & $\begin{array}{c}\text { Chromium concentration } \\
(\mu \mathrm{g} / \mathrm{g} \text { dry mass })\end{array}$ \\
\hline S. cerevisiae & $0.7-4.4$ \\
C. lipolytica & $1.6-3.0$ \\
C. boidinii & $1.1-5.1$ \\
H. platypodis & 3.2 \\
P. kluyveri & 3.0 \\
Y. lipolytica & 0.22 \\
S. starkeyi-henricii & 0.19 \\
\hline
\end{tabular}

The natural source of chromium (i.e. enriched yeast biomass) was proved to be more beneficial to glucose metabolism than $\mathrm{Cr}$-picolinate $[115,116]$ or other $\mathrm{Cr}$ compounds [117-120]. Even more, some publications claim that Cr-picolinate can be cancerogenic [121, 122], what is not the case with chromium enriched yeast biomass [123]. Following current results in the literature and our own results it is obvious that the majority of research is focussed on yeast in aerobic conditions. Anaerobic 
environment, in spite that it is widely extended in technology, is not comprehensively approached in the past. The presence of chromium in yeast biomass originated from anaerobic bioprocesses was also studied in traditional process of must fermentation and it was found that chromium had beneficial effect in S. cerevisiae. However, stronger production of the reduction compounds were found, consequently [124].

\section{Effect of chromium on yeasts' viability}

Chromium can have different effects on yeast metabolism. It can be beneficial if the concentrations are in physiological range. Deficiency symptom from the lack of chromium is not known for yeast, but toxic effects from the excess of it can be recognized clearly with growth inhibition or with analyzing particular biomolecules in the cell (i.e. DNA, RNA, proteins).

Since chromium and also some other metal ions are both essential and potentially toxic, their intracellular concentrations are the subject of precise homeostatic regulation [6].

As chromium is important for humans there were some attempts in the past to isolate yeast with high tolerance to it [125-129].

The problem of metal ions' toxicity and/or resistance is discussed in the literature $[19,57]$.

The adequate methodology for microbial bioassays for the detection of metal toxicity is important [130-132], since different approaches can give different results, which are not comparable at all. If one wants to optimize growth medium, the tolerance to particular metal ion for selected yeast species has to be determined [64]. The survival of living cells depends on their ability to react to alterations in the environment and to appropriately respond to the newly emerged conditions [133]. Knowledge of stress and stress responses is crucial to understand how single-cell and multicellular organisms adapt to changing environmental and physiological conditions [134, 135]. The molecular mechanisms induced upon the exposure of cells to such adverse conditions are commonly designated as stress responses. The aim of stress response mechanisms is to protect cells against the potentially detrimental effects of stress challenges and to repair any molecular damage, and to adjust the metabolism and other cellular processes to the new status [133]. These stress responses involve aspects of sensing, signal transduction, transcriptional and post-translational control, proteintargeting to organelles, bioaccumulation of protectants, and activity of repair functions [136]. 
Redox metals play a major part in the generation of reactive intermediates (free radicals, other reactive intermediates) in the cell $[19,133]$ which are potentially the most dangerous for the cell.

To avoid the problems of stress and consequently toxicity of ions in cell surroundings it is crucial to know yeast tolerance limit and spectrum of ions dangerous for the cell. In case of chromium the screening procedure on agar plates based on concentration gradients was developed (fast and reliable), which can serve for rapid assessment of yeast tolerance to potentially toxic metal ions [128, 137, 138].

These screening tests showed great inter- and intra-generic differences among 23 yeast genera and 49 species. Yeasts from genera Saccharomyces, Candida, Hansenula and Kluyveromyces represented more than $50 \%$ of strains tested. The tolerance to chromium(III) was found to be normally distributed and $6 \%$ of screened population could tolerate up to $6.9 \mathrm{mM} \mathrm{Cr}$ (III) concentration in the medium. Majority (approx. 40\%) of yeast strains tolerated up to $5.8 \mathrm{mM}$ and just $4 \%$ showed tolerance below $1.5 \mathrm{mM} \mathrm{Cr}(\mathrm{III})$ [138].

The mathematical model was established with an aim to characterize yeast viability and mortality.

On the other hand, if more precise data are needed, an advanced procedure may be introduced for precise measurement of yeast viability or mortality. It is more time consuming, but it gives more concise information on yeast characteristics [140]. Viability was defined with four parameters: population condition, cell viability in the buffer and cell viability in the buffer supplemented with the effector and specific cell viability. Mortality was defined with three parameters: cell mortality in the buffer, cell mortality in the buffer supplemented with the effector and specific cell mortality. Parameters were calculated on the bases of total cell count per milliliter and number of viable cells per milliliter in each experimental step.

This model was tested for five chromium(VI) compounds on seven selected yeasts (Fig. 5). The study elucidated that physiological status of yeast population from particular species is not comparable in spite of equal treatment during cultivation.

Population condition demonstrated this status with values in the range from 2.78 to $48.58 \%$ in theoretical scale of $100 \%$. With this model one is able to draw conclusion of chromium to yeast viability/mortality as can be seen in Figure 4 .

Six chromium(III) compounds were assessed by the same model (Fig. 6). Studies of chromium(III) compounds revealed deviations, which could be attributed to different chemistry of chromium(III) and chromium(VI) compounds in aqueous solution $[73,140]$. 
Fig. 4. Model for graphical determination of specific cell viability and specific cell mortality at different concentration of $\mathrm{Cr}(\mathrm{VI})$ for yeasts Saccharomyces cerevisiae ZIM 321 and Schwanniomyces occidentalis ZIM 763 [140]

The aim of these experiments was also to compare toxicity of chromium(III) to chromium(VI) compounds, which are known to be more toxic. The results showed that different species of yeast can exhibit noticeable differences in their ability to tolerate higher concentrations of chromium(III) and chromium(VI).

$\mathrm{CrCl}_{3} \times 6 \mathrm{H}_{2} \mathrm{O}$ and $\mathrm{Cr}\left(\mathrm{NO}_{3}\right)_{3} \times 9 \mathrm{H}_{2} \mathrm{O}$ exhibited the highest toxicity in the case of Saccharomyces cerevisiae ZIM 753 and Candida intermedia ZIM 156, while very low concentrations of all $\mathrm{Cr}(\mathrm{III})$ compounds except $\mathrm{KCr}\left(\mathrm{C}_{2} \mathrm{O}_{4}\right)_{2} \times 3 \mathrm{H}_{2} \mathrm{O}$ were toxic to Saccharomyces diastaticus ZIM 152. However, all tested yeasts showed the greatest survival in the case of $\mathrm{KCr}\left(\mathrm{C}_{2} \mathrm{O}_{4}\right)_{2} \times 3 \mathrm{H}_{2} \mathrm{O}$ [141].

We found $S$. cerevisiae, $S$. paradoxsus and $C$. intermedia to be the most tolerant where an average specific cell viability for all $\mathrm{Cr}(\mathrm{VI})$ compounds at the highest $\mathrm{Cr}(\mathrm{VI})$ concentration of $1000 \mu \mathrm{M}$ was in the range from $13-25 \%$ and $0-2 \%$ in the case of less tolerant yeasts $S$. bayanus, S. pastorianus, $S$. diastaticus and $S$. occidentalis. On average the most toxic compound for all yeasts at all $\mathrm{Cr}(\mathrm{VI})$ conc. was $\mathrm{KCrClO}_{3}$ and the least toxic compound was $\mathrm{K}_{2} \mathrm{CrO}_{4}[139,141]$. 
Fig. 5. Yeast population viability calculated from the data for yeasts included into the study (S. cerevisiae, S. paradoxus, C. intermedia, S. bayanus, S. pastorianus, S. diastaticus, S. occidentalis) presented for particular $\mathrm{Cr}(\mathrm{VI})$ compounds [139]

Fig. 6. Effect of higher concentrations of $\mathrm{Cr}(\mathrm{IIII})$ compounds: $1=\mathrm{CrCl}_{3} \times 6 \mathrm{H}_{2} \mathrm{O}, 2=\mathrm{Cr}\left(\mathrm{NO}_{3}\right]_{3} \times 9 \mathrm{H}_{2} \mathrm{O}$, $3=\mathrm{CrK}\left(\mathrm{SO}_{4}\right]_{2} \times 12 \mathrm{H}_{2} \mathrm{O}, 4=\mathrm{KCr}\left(\mathrm{C}_{2} \mathrm{O}_{4}\right]_{2} \times 3 \mathrm{H}_{2} \mathrm{O}, 5=\mathrm{Cr}_{2}\left(\mathrm{CH}_{3} \mathrm{COO}\right]_{3}, 6=\mathrm{Cr}$-citrate on specific survival of yeast Candida intermedia ZIM 156 [141] 
This might be related to the involved mechanism of detoxification [3, 142], which is based on intracellular quarantine in particular compartment or on blocking transport into the cell.

The most common essential amino acid used in the detoxification of many metals is cysteine, which is found in some yeasts as a dominant residue in the thioneins, or as a component of the $\gamma$-glutamyl peptides which may bind metals. Another possibility is that these proteins might be involved in pumping out of the cell. However, there are some indications in this respect for some metabolically important metals like $\mathrm{Zn}$ (II) [35], but is no data for chromium so far.

Detoxification mechanisms are studied by some researchers lately and they showed that vacuole is involved in this action in normal metabolism in the cell detoxification. When vacuolar-lacking mutants of Saccharomyces cerevisiae were exposed to chromate, they displayed higher sensitivity. However, chromium is bioaccumulated into the cytosolic compartments and not to vacuole also in wild strains [143].

One approach for studying toxicity and tolerance of yeast to chromium(VI) or chromium(III) can be established analytically with a goal to determine intracellular components, which turn on or disappear during prolonged exposure to chromium. During the cultivation of $S$. cerevisiae at dilution rate (D) $0.08 \mathrm{~h}^{-1}$ chromium ions exert a harmful effect on yeast cell growth, cell protein and RNA concentrations [144], what was also the case in batch growth [145]. The toxic effect of chromium ions was found as $21 \%$ reduction of biomass, $9 \%$ reduction of protein and $22 \%$ reduction of total cell RNA during continuous cultivation. In batch cultivation, the effect of chromium ions was recognized in growth rate reduction and extension of lag phase [80].

Analyzing distribution of chromium in the cell showed that fractions with molecular weight higher than 100,000 support the mechanism of detoxification at high concentration levels of intracellular chromium in $S$. cerevisiae. Determination of chromium in this cytosolic biomolecules with high molecular weights supports the idea that fast binding of toxic intracellular chromium ion is possible. This is the generally accepted mechanism of action of other heavy metals [146].

Among cell biosynthetic products, metallothionein, the specially designed proteinous molecules for attracting metals (especially toxic ions) are discovered. One group of metallothionein-like molecules found in yeast $S$. cerevisiae is the most studied low molecular weight-cysteine-rich protein for $\mathrm{Cu}$ binding [147]. Lately, Ballatori claimed glutathione mercaptides as transport forms of metal ions in the yeast cells [148]. 


\section{Effect of chromium on yeast genome}

Toxicity of chromium is discussed elsewhere $[55,149,150]$ since it is important in industry and in life processes. However, interference and all positive and/or negative actions of chromium compounds within the yeast cell and its metabolism is focussed on genome since cumulative mutation can effect future development and expression of genetic informations in DNA structure.

According to early observation, chromium (VI) is areactive towards DNA under physiological conditions in vitro [69]. However, in vivo the reduction of chromium(VI) by cellular reductants in cell culture (the microsomal cytochrome P-450 system, mitochondrial electron transport chain complexes, aldehyde oxidase, hydrogen peroxide, scorbate and thiols) to the reactive intermediates, including $\mathrm{Cr}(\mathrm{VI})$ thioester, $\mathrm{Cr}(\mathrm{V}), \mathrm{Cr}(\mathrm{IV})$ species and free radicals (hydroxyl and thiol radicals), is thought to be an important step in the mechanism of $\mathrm{Cr}(\mathrm{VI})$ induced DNA damage [69, 151-155].

There are many publications dealing with DNA lesions induced by chromium(VI) in vivo as well as chromium(III) compounds in vitro, but they seldom use yeast as a model organism. One can find publications on Cr-DNA adducts, DNADNA cross links (DDC) [156, 157], DNA-proteins cross links (DPC) [158] and DNA brakes- single and double [68, 56, 154, 159-161], proving direct reactivity of chromium with DNA. Some of them are dealing with an interference of chromium(III) compounds in vitro with enzymes in DNA processing (i.e. polymerase) $[152,162]$, or with chromium bounded to DNA on the way to alter cleavage side for restriction endonucleases [163]. Many publications deal with free radicals in gene toxicity. Combination of hydrogen peroxide and chromium(III) and chromium(VI) showed DNA damage mediated with Fenton-like reaction [164-166]. Further interesting observation that metal ion-dependent hydrogen peroxide-induced DNA damage is more sequence specific than metal specific opened new dimension of the problem [167].

Few publications claim interference with particular system included in detoxification in the cell. Alcedo and co-workers found chromium(VI) altering metalinducible expression, but not basal expression of the metallothionein gene. They used this as a proof for suggesting that chromium(VI) has priority to inducible genes [168].

Regarding mutagenesis in yeast there were many publications dealing with the problem of chromium twenty years ago. The majority of them were oriented just to detect mutagenic effect of chromium in different preparations [117, 120]. However, there are some publications, which gave suitable start for further research in the field, like induction of petit mutants by calcium chromate. Its toxic and mutagenic effects on the mitochondria of $S$. cerevisiae were showed $[169,170]$. In the same organism, 
induction of reverse mutation and mitotic gene conversion by some metal compounds was demonstrated [171].

In the last decade, rapid estimation of chromosomal damage in yeast (i.e. radiation-induced) has been evaluated by pulsed field gel electrophoresis [172-174]. The effects of chromium(VI) compound $\mathrm{K}_{2} \mathrm{Cr}_{2} \mathrm{O}_{7}$ can be visualized in the same manner [175]. PFGE together with densitometry offers opportunity to follow DSB (DoubleStranded Brakes), which were detected as smear of DNA on the gel after yeasts were exposed to chromium(VI). They found that in in vivo conditions chromium(VI) compound $\mathrm{K}_{2} \mathrm{Cr}_{2} \mathrm{O}_{7}$ induced double-stranded brakes of chromosomal DNA in all $S$. cerevisiae tested.

Further studies revealed that recombination repair (gene Rad51) reduced gene toxicity of chromium compounds in exponential growth phase for all applied concentrations up to $20 \mathrm{mM}$ of chromium compounds. Excision repair of DNA damage (gene RAD1) was found in the stationary growth phase as crucial for reducing gene toxicity of $\mathrm{K}_{2} \mathrm{Cr}_{2} \mathrm{O}_{7}$.

Fig. 7. The effects of chromium(III) compound $\mathrm{K}_{2} \mathrm{Cr}_{2} \mathrm{O}_{7}$ on chromosomal DNA in yeast S. cerevisiae ZIM 465 in vitro (S1-detected through S1 nuclease activity-cutting SSB on DNA; OD-Optical density) [176]

Additionally, the cells were exposed to chromium(VI) in exponential growth phase and they evidently have excision repair mechanism at high concentration range. 
Since lethality is correlated to chromium concentration, the study of cell response showed gene RAD18 responsible for mutation repair. This gene is active in exponential growth phase, but not in stationary phase [176]. As a consequence of $\mathrm{K}_{2} \mathrm{Cr}_{2} \mathrm{O}_{7}$ treatment, chromosomal aberrations were found in S. cerevisiae in vivo, specifically on one chromosome (Figure 7). Proposed chromium induced damage was confirmed by survival test with rad51 mutant, since rad51 mutant has no mechanism of repair as is common in wild strain, consequently their survival was strongly reduced. Singlestranded brakes (SSB) were tested in in vitro conditions with chromium(III). Nuclease S1 showed to be appropriate tool for detection of spots at chromosomal DNA in S.cerevisiae where this DNA damage could occurred. Results suggested that chromium(III) induces structural changes in DNA structure and consequently SSB [176]. Today it is stated that chromium-induced DNA damage can be repaired after mutagenesis [177, 178], since repair mechanism are not damaged by chromium oxidation.

Cells have evolved a number of capabilities to repair macromolecules that are damaged and to inactivate reactive intermediates. Yeast cells contain enzymatic as well as non-enzymatic defense mechanisms against the harmful effects of reactive deviates. The genes encoding components of this defense apparatus, such as those involved in glutathione or thioredoxin biosynthesis, display increased expression after stress challenge. Glutathione and thioredoxin are normally involved in cellular redoxreactions, in particular those involved in the establishment and maintenance of the tertiary structure of proteins [133].

\section{Conclusions}

Chromium is an element in yeast metabolism, but when accumulated in excess, becomes toxic. The form and concentration of chromium in the macro- and microenvironment of the yeasts are important. Chromium(VI) with its negative charge enters cell more easily than chromium(III), which is positively charged in physiological conditions. However, all the transport mechanisms are still not clearly defined. Since toxicity is connected with chromium concentration, its manifestation in metabolism is proportional with amount, which can enter the cell and interfere with biological functions. DNA was showed to be damaged by chromium(VI) in vivo and chromium(III) in vitro. Single-stranded and double-stranded brakes are induced by chromium. During cultivation in batch, fed-batch and continuous processes reduction of RNA, proteins and biomass yield are present. However, there are yeasts, which tolerate higher concentrations of chromium and are more suitable for bioprocessing. 
Their fast screening can be conducted by the gradient agar plate method, followed by cell viability/ mortality method, which select adequate yeast. Yeast biomass showed to be able to uptake high amount of chromium by biosorption and bioaccumulation. The ratio between total and organically bound chromium was good. However, the function of chromium in glucose tolerance factor and role of chromium in yeast metabolism remains in focus of current research. The question if metallothionein-like complex, which is able to bind chromium in yeast remains to be opened for further research.

Acknowledgements. The authors express thanks to Ministry of Science of Republic of Slovenia, which supported this project (J4-7454). Ms V.R.D expresses her gratitude to Slovenian Science foundation for fellowship. Students M.S. and, M.B. would like to acknowledge for fellowship to Slovenian Ministry of Science and Technology and M.P., and P.J. to Ministry of Education Republic of Slovenia. Special thanks to I. Hočevar for kind help with references.

\section{References}

1. Williams,R.J.P.: The biochemistry of sodium, potassium, magnesium and calcium. Q Rev Chem Soc 24, 331 (1970).

2. Borst-Pouwels,G.W.F.H.: Ion transport in yeast. Biochim Biophys Acta 650, 88 (1981).

3. Blackwell,K.J., Singleton,I., Tobin,J.M.: Metal cation uptake by yeast: A review. Appl Microbiol Biotechnol 43(4), 579 (1995).

4. Walker,M.G.: Yeast Physiology and Biotechnology. Wiley, Toronto, 1994. p. 350.

5. Youatt,J.: Calcium and microorganisms. Crit Rev Microbiol 19(2), 83 (1993).

6. Eide,D., Guerinot,M.L.: Metal ion uptake in eucaryotes. ASM News 63(4), 199 (1997)

7. Cowan,J.A.: Inorganic Biochemistry. Wieley-VCH, New York, 1997. p. 440.

8. Jones,R.P., Greenfield,P.F.: A review of yeast ionic nutrition: Part I: Growth and fermentation requirements. Process Biochem 19(4), 48 (1984).

9. Jones,R.P., Gadd,G.M.: Ionic nutrition of yeast - physiological mechanisms involved and implications for biotechnology. Enzyme Microb Tech 12, 402 (1990).

10. Schelenz,R., Parr,R.M., Zeiller,E.: Clements-S chromium in biological materials - IAEA intercomparison results. Z Anal Chem 333(1), 33 (1989).

11. WHO: Trace Elements in Human Nutrition and Health. World Health Organization, Geneva, 1996. pp. 155-160.

12. Mertz,W.: Chromium occurrence and function in biological systems. Physiol Rev 49(2), 163 (1969).

13. Mertz,W.: Chromium. Curr Top Nutr Dis 12, 259 (1984).

14. Ducros,V.: Chromium metabolism: A literature review. Biol Tr Elem Res 32, 65 (1992).

15. Anderson,R.A.: Effects of chromium on body composition and weight loss. Nutr Rev 56(9), 266 (1998).

16. Mertz,W.: Chromium in human nutrition: A review. J Nutr 123, 626 (1993).

17. Anderson,J.J.B.: Chromium as an essential nutrient for humans. Regul Toxicol Pharm 26, 35 (1997). 
18. Whitney,E.N., Cataldo,C.B., Rolfes,S.R.: Understanding normal and clinical nutrition. 5th ed. ITP, Belmot, 1998. pp. 450-484.

19. Stohs,S.J., Bagchi,D.: Oxidative mechanisms in the toxicity of metal ions. Free Radical Bio Med 18(2), 321 (1995).

20. Mertz,W.: A perspective of mineral standards. Nutr Rev 56(6), 174 (1998).

21. Anderson,J.J.B., Allen,J.C.: Nutrition of macrominerals and trace elements. In Goldberg,I. (ed.): Functional Foods. Chapmann \& Hall, New York, 1994. p. 323.

22. Pszczola,D.E.: Addressing functional problems in fortified foods. Food Technol 52(7), 38 (1998).

23. Gadd,G.M., White,C.: Microbial treatment of metal pollution - a working Biotechnology? Trends Biotech 11(8), 353 (1993).

24. Tobin,J.M., White,C., Gadd,G.M.: Metal accumulation by fungi: Application in environmental biotechnology. J Ind Microbiol 13, 126 (1994).

25. Lovley,R.D., Coates,J.D.: Bioremediation of metal contamination. Curr Opin Biotech 8(3), 285 (1997).

26. Ul Haq,R., Shakoori,A.R.: Microbiological treatment of industrial wastes containing toxic chromium involving successive use of bacteria, yeast and algae. World Journal Of Microbiology \& Biotechnology 14(4), 583 (1998).

27. Volesky,B.: Biosorption of Heavy Metals. CRC Press, Boston, 1990. p. 396.

28. Krauter,P., Melli,R., Williams,K., M.s,S.: Removal of $\mathrm{Cr}(\mathrm{VI})$ from groundwater by Saccharomyces cerevisiae. Biodegradation 7(4), 277 (1996).

29. Brady,D.: Biosorption of heavy metal cations by non-viable yeast biomass. Environ Technol 15(5), 429 (1997).

30. Pawlisz,A.V., Kent,R.A., Schnider,U.A., Jefferson,C.: Canadian water quality guidelines for chromium. Environ Toxic Water Qual 12(2), 123 (1997).

31. Losi,M.E., Amrhein,C., Frankenberger,W.T.: Environmental biochemistry of chromium. Rev Environ Contam Toxic 136, 91 (1994).

32. Squibb,K.S., Snow,E.T.: Chromium. In Corn,M. (ed.): Handbook of Hazardous Materials. Academic Press, San Diego, 1993. pp. 127-144.

33. Lee,J.D.: Concise Inorganic Chemistry. 5th ed. Chapman and Hall, London, 1996. pp. 713-733.

34. Kaim,W., Schwederski,B.: Bioinorganic Chemistry: Inorganic Elements in the Chemistry of Life. JW\&Sons, 1994. p. 401.

35. Winkelmann,G., Winge,R.D.: Metal Ions in Fungi. Marcel Dekker Inc., Hong Kong, 1994. p. 507.

36. Volesky,B.: Advances in biosorption of metals: Selection of biomass types. FEMS Microbiol Rev 14(4), 291 (1994).

37. Arnold,W,N.: Yeast cell envelopes: Biochemistry, biophysics and ultrastructure. CRC, Boca Raton, 1981. Vol 1 1-125; Vol 2 1-171.

38. Frausto Da Silva,J.J.R., Williams,R.J.P.: The Biological Chemistry of the Elements: The Inorganic Chemistry of Life. Claredon Press, Oxford, 1993. p. 561.

39. Figueria,M.M., Volesky,B., Cimineelli,V.S.T.: Assessment of interference in biosorption of heavy metal. Biotechnol Bioeng 54, 344 (1997).

40. Kapoor,A., Viraraghavan,T.: Fungal biosorption - An alternative treatment option for heavy metal bearing wastewaters: A review. Bioresource Technol 53, 105 (1995). 
41. Nagodawithana,T.W.: Products and uses of yeast and yeast-like fungi. In Arora,D.K., Mukerji,K.G., Marth,E.H. (eds): Handbook of Applied Mycology: Foods and Feeds. Marcel Dekker Inc., Hong Kong, 1991. pp. 553-603.

42. Mertz,W.: Interaction of chromium with insulin: a progress report. J Nutr 128, 375 (1998).

43. Mertz,W.: Reply to the letter of Dr. Vincent. Letter to the editor. J Nutr 124, 119 (1994).

44. Hunt,A.E.: Effect of Chromium Supplementation on Hair Chromium Concentration and Diabetic Status. Dissertation. Colorado State University, Colorado, 1983. p. 88.

45. Anderson,R.A.: Chromium - physiology. In Macrae,R., Robinson,R.K., Sadler,M.J. (eds): Encyclopedia of Food Science, Food Technology and Nutrition. Academic Press, Toronto, 1993. pp. 976-979.

46. Lentini,A., Jones,R.D., Wheatcroft,R., Lim,Y.H., Fox,C., Hawthorne,D.B., Kavanagh,T.E.: Metal ion uptake by yeast. In Proceedings of 21st Convention, 4-9 March, New Zealand. Auckland. The Institute of Brewing, Auckland, 1990. pp. 158-163.

47. Engl,A., Kunz,B.: Biosorption of heavy metals by Saccharomyces cerevisiae; effects of nutrient conditions. J Chem Tech Biotechnol 63, 257 (1995).

48. Volesky,B., May-Phillips,H.A.: Biosorption of heavy metals by Saccharomyces cerevisiae. Appl Microbiol Biotechnol 42(5), 797 (1995).

49. Janzso,B., Suhajda,A., Pais,I.: Yeasts enrichment with micro-elements. In Turner,A. (ed.): Food Technology International. Sterling Publications Ltd., Hong Kong, 1993. pp. 173-177.

50. Hegoczki,J., Suhajda,A., Janzso,B., Vereczkey,G.: Preparation of chromium enriched yeasts. Acta Aliment 26, 345 (1997).

51. Batič,M., Raspor,P.: Effect of cultivation mode on bioprocess of chromium yeast biomass enrichment. Eur J Physiol 439, 273 (2000).

52. Mirsky,N., Berdicevsky,I.: Effects of insulin and glucose tolerance factor on glucose uptake by yeast cells. Biol Signals 3, 271 (1994).

53. Haylock,S.J., Buckley,P.D., Blackwell,L.F.: The relationship of chromium to the glucose tolerance factor. II. J Inorg Biochem 19(2), 105 (1983).

54. Simonoff,M., Shapcott,D., Alameddine,S., Sutter-Dub,M.T., Simonoff,G.: The isolation of glucose tolerance factors from brewer's yeast and their relation to chromium. Biol Trace Elem Res 32(1), 25 (1992).

55. Barceloux,D.G.: Chromium. J Toxicol Clin Toxicol 37(2), 173 (1999).

56. ATSDR, Toxicological profile for chromium. U.S. Department of Health and Human Services, Atlanta, 1993.

57. Katz,S.A., Salem,H.: The toxicology of chromium with respect to its chemical speciation: A review. J Appl Toxicol 13(3), 217 (1993).

58. Buerge,I.J., Hug,S.I.: Kinetics and $\mathrm{pH}$ dependance of chromium(VI) reduction by iron(II). Environ Sci Technol 31(5), 1426 (1997).

59. Muller,G., Barclay,S.J., Raymond,K.N.: The mechanism and specificity of iron transport in Rhodotorula pilimanae probed by synthetic analogs of rhodotorulic acid. J Biol Chem 260(26), 13916 (1985).

60. Hughes,M.N., Poole,R.K.: Metals and Microorganisms. Chapman and Hall, New York, 1989. p. 412.

61. Ford,T., Mitchell,R.: Microbial transport of toxic metals. In Mitchell,R. (ed.): Environmental Microbiology. Wiley-Liss, Singapore, 1992, pp. 83-101. 
62. Rovira,R.F., Blanch,M.J.L.: Chromium - properties and determination. In Macrae,R., Robinson,R.K., Sadler,M.J. (eds): Encyclopedia of Food Science, Food Technology and Nutrition. Academic Press, Toronto, 1993. pp. 972-976.

63. Hughes,M.N., Poole,R.K.: Metal speciation and microbial growth - the hard (and soft) facts. J Gen Microb 137, 752 (1991).

64. Babich,H., Schiffenbauer,M., Stotzky,G.: Comparative toxicity of trivalent and hexavalent chromium in fungi. Bull Environ Toxicol 28, 452 (1982).

65. Sakurai,H., Tachikawa,T., Shimomura,S.: Interaction of chromium with thiol - containing proteins evidence for the formation of trivalent chromium. Anal Lett B 11(11), 879 (1978).

66. Kong,S., Yonge,D.R., Johnstone,D.L., P.Sen, J.N., Brouns,T.M.: Competing ion effect on chromium adsorption with fresh and starved sub-surface bacterial consortium. Biotechnol Lett 15(1), 87 (1993).

67. Kumpulainen,J., Koivistoinen,P.: Effects of glucose and chromium(III) concentrations in the medium on the uptake of ${ }^{51} \mathrm{Cr}$ by brevers's yeasts. Bioinorg Chem 8, 431 (1978).

68. Wetterhahn,K.E., Hamilton,J.W., Aiyar,J., Borges,K.M., Floyd,R.: Mechanism of chromium(VI) carcinogenesis. Reactive intermediates and effect on gene expression. Biol Trace Elem Res 21, 405 (1989).

69. Wetterhahn,K.E., Hamilton,J.W.: Molecular basis of hexavalent chromium carcinogenicity: Effect on gene expression. Sci Total Environ 86, 113 (1989).

70. Smith,F.W., Hawkesford,M.J., Prosser,I.M., Clarkson,D.T.: Isolation of a cDNA from Saccharomyces cerevisiae that encodes a high affinity sulphate transporter at the plasma membrane. Mol Gen Genet 247, 709 (1995).

71. Cherest,H., Davidian,J., Thomas,D., Benes,V., Ansorge,W., Surdin-Kerjan,Y.: Molecular characterization of two high affinity sulfate transporters in Saccharomyces cerevisiae. Genetics 145, 627 (1997).

72. Andre,B.: An overview of membrane transport proteins in Saccharomyces cerevisiae. Yeasts 11, 1575 (1995).

73. Raspor,P., Batič,M., Drašlar,K., Jamnik,P., Josić,D., Milačič,R., Paš,M., Recek,M., Režić-Dereani,V., Skrt,M.: The problem of chromium compounds bioaccumulation in yeasts. In 20th International Specialized Symposium on Yeasts, May 23-27, 1999, Smolenice, Slovakia. Yeast Cell Surfaces and Membrane Phenomena: Programme and Abstracts. Czechoslovak Society for Microbiology, Czech and Slovak Yeast Commission, Smolenice, 1999. pp. 56-58.

74. Avery,S.V., Tobin,J.M.: Mechanisms of strontium uptake by laboratory and brewing strains of Saccharomyces cerevisiae. Appl Environ Microbiol 58(12), 3883 (1992).

75. Brady,D., Duncan,J.R.: Binding of heavy metals by the cell walls of Saccharomyces cerevisiae. Appl Microbiol Biotechnol 41, 149 (1994).

76. White,C., Gadd,G.M.: The uptake and cellular distribution of zinc in Saccharomyces cerevisiae. J Gen Microbiol 133, 727 (1987).

77. Brady,D., Stoll,A., Duncan,J.R.: Biosorption of heavy metal cations by non-viable yeast biomass. Environ Technol 15(5), 429 (1994).

78. Batič,M., Štupar,J., Bayer,K., Raspor,P.: Effect of chromium(III) in batch mode on Saccharomyces cerevisiae. Biometals 1999, in press.

79. Brady,D., Duncan,J.R.: Cation loss during accumulation of heavy metal cations by Saccharomyces cerevisiae. Biotechnol Lett 16(5), 543 (1994). 
80. Batič,M., Raspor,P.: Uptake and bioaccumulation of $\mathrm{Cr}(\mathrm{III})$ in yeast Saccharomyces cerevisiae. Food Technol Biotechnol 36, 291 (1998).

81. Zavašnik,V., Batič,M., Štupar,J., Raspor,P.: Mineral uptake by yeast biomass. In Raspor,P., Pitako,D., Hočevar,I. (eds): 1. slovenski kongres o hrani in prehrani z mednarodno udeležbo, 21-25. april 1996, Bled. Tehnologija, hrana, zdravje. Knjiga del. Association of Food and Nutrition Specialists of Slovenia, Ljubljana, 1997. pp. 199-203.

82. Recek,M., Raspor,P.: Accumulation of chromium added at different yeast growth phase. In BoleHribovšek,V., Ocepek,M., Klun,N. (eds): 2. kongres mikrobiologov Slovenije z mednarodno udeležbo, Portorož, Slovenija, 27-30. september 1998. Zbornik s programom. Slovensko mikrobiološko društvo, Ljubljana, 1998. pp. 243-247.

83. Kosman,D.J.: Transition Metal ion Uptake in Yeast and Filamentous Fungi. In Winkelmann,G., Winge,R.D. (eds): Metals Ions in Fungi. Marcel Dekker Inc., Hong Kong, 1994. pp. 1-39.

84. Batič,M.: Yeast Cultivation in Media Loaded with Zinc and Chromium. Dissertation Thesis. University of Ljubljana, Biotechnical Faculty, Department of Food Science and Technology, Ljubljana, 1995. pp. $1-140$.

85. Gadd,G.M.: Biosorption. Chem Ind 13, 421 (1990).

86. Simonovska,M., Josić,D., Raspor,P.: Separation of low-molecular-weight chromium-binding polypeptides from Candida intermedia. In 18th International Symposium on Separation of Proteins, Peptides \& Polynucleotides ISPPP'98, November 1-4, 1998, Vienna, Austria. Vienna, 1998. p. 47.

87. Kakoku: Use of microorganisms as metal ion carriers in animal feedstuffs. Patent, JP-; J57159447; 01.10 .82

88. Skogerson,E.L.: Method for the production of chromium yeast. Patent US-4348434; 09.07.82.

89. Skogerson,E.L.: Method for the production of chromium yeast. Patent EP-94979; 03.09.86.

90. Szalay,A.: Concentrated glucose tolerance factor chromium complex brewers yeasts and process for producing same. Patent US-US4343905; 10.08.82.

91. Gottlieb,L., Rahman,R.L.O.: Improving of metal adsorption properties of biomass Patent IL-0117080; 06.02 .97

92. Mannino,S., Cavazzoni,V.: Mineral content of Candida yeasts grown on different substrates. Lebensmitt Wiss Technol 13(1), 34 (1980).

93. Schwartz,K., Mertz,W.: A glucose tolerance factor and its differentiation from factor 3. Arch Biochem Biophy 72, 515 (1957).

94. Toepfer,E.,W., Mertz,W., Roginski,E.E., Polansky,M.M.: Chromium in foods in relation to biological activity. J Agr Food Chem 21(1), 69 (1973).

95. Starich,G.H., Blincoe,C.: Dietary chromium-forms and availabilities. Sci Total Environ 18, 443 (1983).

96. Shepherd,P.R., Elwood,C., Buckley,P.D., Blackwell,L.F.: Glucose tolerance factor potentiation of insulin action in adipocytes from rats raised on a torula yeast diet cannot be attributed to a deficiency of chromium or glucose tolerance factor activity in the diet. Biol Trace Elem Res 32, 109 (1992).

97. Davies,D.M., Holdsworth,E.S., Sherriff,J.L.: The isolation of glucose tolerance factors from brewer's yeast and their relationship to chromium. Biochem Med 33(3), 297 (1985).

98. Mirsky,N., Weiss,A., Dori,Z.: Chromium in biological systems. I Some observations on glucose tolerance factor in yeast. J Inorg Biochem 12, 11 (1980).

99. Mirsky,N., Weiss,A., Dori,Z.: The effect of glucose tolerance factor in glucose uptake by yeast cells. J Inorg Biochem 15(3), 275 (1981). 
100. Votava,H.J., Carole,J.H., Evans,G.W.: Isolation and partial characterisation of a 51Cr complex from brewers yeasts. Biochem Biophys Res Commun 55(2), 312 (1973).

101. Kumpulainen,J., Koivistoinen,P., Lahtinen,S.: Isolation, purification, and partial chemical characterization of chromium(III) fractions existing in brewer's yeast and Sabouraud's liquid medium. Bioinorg Chem 8(5), 419 (1978).

102. Toepfer,E.W., Mertz,W., Polansky,M.M., Roginski,E,E., Wolfe,W.R.: Preparation of chromium containing material of glucose tolerance factor activity from brewer's yeasts extracts and by synthesis. J Agr Food Chem 25,162 (1977).

103. Urumow,T., Wieland,O.H.: On the nature of the glucose tolerance factor from yeast. Horm Metabol Res 16, 51 (1984).

104. Hwang,D.L., Lev-Ran,A., Papoian,T., Beech,W.K.: Insulin-like activity of chromium-binding fractions from brewer's yeast. J Inorg Biochem 30, 219 (1987).

105. Haylock,J.S., Buckley,P.D., Blackwell,L.F.: Separation of biologically active chromium-containing complexes from yeast extracts and other sources of GTF activity. J Inorganic Biochem 18, 195 (1983).

106. Vincent,J.B.: Mechanisms of chromium Action: Low Molecular Weight Chromium Binding Substance. J Am College of Nutrition 18, 6 (1999).

107. Barnett,J., O'Brein,P.: Chromium (III) and the glucose tolerance factor. Poyhedron 4, 1 (1985).

108. Sumrall,K.H., Vincent,J.B.: Is the glucose tolerance factor an artifact produced by acid hydrolysis of low molecular weight chromium binding substance. Polyhedron 16(23), 4171 (1997).

109. Holdsworth,E.S., Appleby,G.: Assays of glucose tolerance factor and its mode of action, studied with brewer's yeast. J Inorg Biochem, 21(1), 31 (1984).

110. Holdsworth,E.S., Neville,E.: Effects of extracts of high- and low-chromium brewer's yeast on metabolism of glucose by hepatocytes from rats fed on high- or low-Cr diets. Br J Nutr 63(3), 623 (1990).

111. O'Donoghue,E.M., Cooper,J.A., Jackson,T.G., Shepherd,P.R., Buckley,P.D., Blackwell,L.F.: Identification of peptides from autolysates of Saccharomyces cerevisiae that exhibit glucose tolerance factor activity in a yeast assay. Int J Biochem 22(8), 841 (1990).

112. Beran,M., Stahl,R., Beran,M.Jr.: Glycaemic activity of (III)-beta-nicotinamide adenine dinucleotide phosphate complex and its presence in yeast extracts. Analyst 120(3), 979 (1995).

113. Batič,M., Lenarčič,D., Smole Možina,S., Štupar,J., Raspor,P.: Resistance on chromium (Cr3+) and zinc (Zn2+) in yeast. In Raspor,P. (ed.): Additives - Technology - Health: Proceedings of the 16th Bitenc's Food Days and 1st Symposium of Food and Nutrition Professionals, Bled, Slovenia, June 9-10, 1994. Biotehniška fakulteta, Oddelek za živilstvo, Ljubljana, 1994. pp. 265-268.

114. Batič,M., Raspor,P.: Nonconventional inorganic nutrient in yeast: chromium. In Raspor,P., SmoleMožina,S., Zagorc,T., Batič,M. (eds): Yeast Nutrition and Natural Habitats: Book of Abstracts. Biotechnical Faculty, Slovene Microbiological Society, International Commission for Yeasts, Ljubljana, 1997. p. SOP2-06.

115. Reading,S.A.: Chromium picolinate. J Fla Med Assoc 83(1), 29 (1996).

116. Cerulli,J., Grabe,D.W., Gauthier,I., Malone,M., McGoldrick,M.D.: Chromium picolinate toxicity. Ann Pharmacother 32(4), 428 (1998).

117. Bianchi,V., Levis,A.G.: Mechanisms of chromium genotoxicity, carcinogenic and mutagenic metal compounds. In Merian,E., Frei,R.W., Hardi,W., Schlatter,C.H. (eds): Environmental and Analytical 
Chemistry and Biological Effects. Gordon and Breach, Science Publishers, New York, 1985. pp. 269293.

118. Galli,A., Boccardo,P., Del Carratore,R., Cundari,E., Bronzetti,G.: Conditions that influence the genetic activity of potassium dichromate and chromium chloride in Saccharomyces cerevisiae. Mutat Res 144, 165 (1985).

119. Bronzetti,G., Galli,A., Boccardo,P., Vellosi,R., Del Carratore,R.: Genotoxicity of chromium in vitro on yeast: Interaction with DNA. Toxicol Environ Chem 13(1-2), 103 (1986).

120. Beyersmann,D., Koster,A.: On the role of trivalent chromium in chromium genotoxicity. Toxicol Environment Chem 14(1-2), 11 (1987).

121. Stearns,D.M., Wise,J.P., Patierno,S.R., Wetterhahn,K.E.: Chromium(III) picolinate produces chromosome damage in Chinese hamster ovary cells. FASEB J 9(15), 1643 (1995).

122. Speetjens,J.K, Collins,R.A., Vincent,J.B.: Woski,S.A.: The nutritional supplement chromium(III) tris(picolinate) cleaves DNA. Chem Res Toxicol 12(6), 483 (1999).

123. Li,X.I., Shen,J., Bai,C.J., Mendelsohn,M.L.: On toxicity and mutagenicity of chromium rich brewer's yeast. In Albertini,R.J. (ed.): Progress in Clinical and Biological Research, vol. 340. Mutation and the Environment. Wiley, New York, 1990. pp. 199-204.

124. Ciolfi,G., Spera,G., Garofolo,A.: The yeast metabolism with regard to the nickel, chrome and manganese, cations presence in the medium during alcoholic fermentation. Ind Bevande 29, 383 (1997).

125. Martini,A.V., Cardinali,G., Barcaccia,S., Baldi,F.: Preliminary study on a yeast able to resist high concentrations of chrome. Ann Fac Agrar Univ Stud Perugia 42, 695 (1990).

126. Baldi,F., Vaughan,A.M., Olson,G.J.: Chromium(VI)-resistant yeast isolated from a sewage treatment plant receiving tannery wastes. Appl Environ Microbiol 56(4), 913 (1990).

127. Pepi,M., Baldi,F.: Modulation of chromium(VI) toxicity by organic and inorganic sulfur species in yeasts from industrial wastes. Biometals 5(3), 179 (1992).

128. Lenarčič,D.: Impact of Chromium and Zinc on Yeast Growth. Graduation Thesis. Biotehniška fakulteta, Oddelek za živilstvo, Ljubljana, 1993. p. 52.

129. Batič,M., Zver,D., Štupar,J., Raspor,P.: Can yeasts accumulate chromium (Cr3+) into the cell? Acta Microbiol et Immunologica Hung 43(2-3), 239 (1996).

130. Nestmann,E.R., Matula,T.I., Douglas,G.R., Bora,K.C., Kowbel,D.J.: Detection of the mutagenic activity of lead chromate using a battery of microbial tests. Mutat Res 66, 357 (1979).

131. Bukowski,J.A, Goldstein,M.D., Korn,L.R., Johnson,B.B.: Biological markers in chromium exposure assessment: Confounding variables. Arch Environ Health 46(4), 230 (1991).

132. Codina,J.C., Perez-Garcia,A., Romero,P., De Vicente,A.: A comparison of microbial bioassays for the detection of metal toxicity. Arch Environ Contam Toxicol 25(2), 250 (1993).

133. Hohmann,S., Mager,W.H.: Yeast Stress Responses. Springer- Verlag, Heidelberg, 1997. p. 183.

134. Ruis,H., Schueller,C.: Stress signaling in yeast. Bioassays 17(11), 959 (1995).

135. Jamieson,D.J.: Oxidative stress responses of the yeasts S. cerevisiae. Yeast 14, 1511 (1998).

136. Attfield,P.V.: Stress tolerance: The key to effective strains of industrial baker's yeast. Nature Biotechnol 15, 1351 (1997).

137. Lenarčič,D., Batič,M., Smole-Možina,S., Štupar,J., Raspor,P.: Resistance to chromium (Cr3+) and zinc (Zn2+) in yeast. AAMJ, Alpe Adria Microbiol J 3(2), 142 (1994).

138. Batič,M., Lenarčič,D., Štupar,J., Raspor,P.: Rapid method for screening the tolerance of yeasts to zinc (II) and chromium (III). J Rapid Methods Autom Microbiol 4, 265 (1996). 
139. Jamnik,P., Paš,M., Batič,M., Raspor,P.: Effect of Cr(VI) compounds on yeasts viability. In Raspor,P., Smole-Možina,S., Zagorc,T., Batič,M. (eds): Yeast Nutrition and Natural Habitats: Book of Abstracts. Biotechnical Faculty, Slovene Microbiological Society, International Commission for Yeasts, Ljubljana, 1997. p. P2-06.

140. Raspor,P., Batič,M., Jamnik,P.: Measurement of yeast viability/mortality in the presence of chromium(VI). Food Technol Biotechnol 37(2), 81 (1999).

141. Paš,M., Prah,S., Raspor,P.: Effect of $\mathrm{Cr}(\mathrm{III})$ compounds on yeasts survival. Zbornik Biotehniške fakultete Res Rep Biotech Fac Ljubljana 73, 187 (1999).

142. Ehrlich,H.L.: Microbes and metals. Appl Microbiol Biot 48, 687 (1997).

143. Gharieb,M.M., Gadd,G.M.: Evidence for the involvement of vacuolar activity in metal(loid) tolerance: vacuolar-lacking and -defective mutants of Saccharomyces cerevisiae display higher sensitivity to chromate, tellurite and selenite. Biometals 11(2), 101 (1998).

144. Batič,M., Zver,D., Štupar,J., Raspor,P.: Yeasts growth in stress concentrations of heavy metal. In SáCorreia,I., Fialho,A. M., Viegas,C.A. (eds): Microbial Response to Stress: What's New and How Can it be Applied? European Federation of Biotechnology, Working Party Microbial Physiology, Sociedade Portuguesa de Biotecnologia, Sesimbra, 1997. p. 134, P84.

145. Batič,M., Štupar,J., Raspor,P.: Yeast growth on chromium $(\mathrm{Cr} 3+)$ enriched media. In Yeast Growth \& differentiation: Biotechnological, Biochemical \& Genetic Aspects: International Specialised Symposium on Yeast: 27th August - 31st August 1995: Edinburg Conference Centre at Heriot-Watt University, Riccarton, Edinburgh: Abstracts. Heriot-Watt University, Edinburgh, 1995. p. P3.

146. Gadd,G.M.: Fungi and yeasts for metal accumulation. In Ehrlich,H.L., Brierley,C.L. (eds): Microbial Mineral Recovery. McGraw-Hill Publishing Company, Toronto, 1990. pp. 249-275.

147. Butt,T., Ecker,D.J.: Yeast metallothionein and applications in biotechnology. Microbiol Rev 51(3), 351 (1987).

148. Ballatori,N.: Glutathione mercaptides as transport forms of metals. Adv Pharmacology 27, 271 (1994).

149. Pounds,J.G.: The toxic effects of metals. In Williams,P.L., Burson,J.L. (eds): Industrial Toxicology: Safety and Health Applications in the Workplace. Van Nostrand Reinhold Company, New York, 1985. pp. 197-210.

150. Thiele,D.J.: Metal detoxification in eukaryotic cells. University of Michigan, Medical School, Crisp Data Base National Institutes of Health, Michigan, 1998.

151. Bose,R.N., Moghaddas,S., Gelerinter,E.: Long-lived chromium(IV) chromium(V) metabolites in the chromium(VI)-glutathione reaction: NMR, ESR, HPLC, and kinetic characterization. Inorg Chem 3, 1987 (1992).

152. Snow,E.T., Xu,L.: Chromium(III) bound to DNA templates promotes increased polymerase processivity and decreased fidelity during replication in vitro. Biochem 30, 11238 (1991).

153. Snow,E.T.: A possible role for chromium(III) in genotoxicity. Environ Health Persp 92, 75 (1991).

154. Snow,E.T.: Metal carcinogenesis: Mechanistic implications. Pharmacol Therapeut 53, 31 (1992).

155. Snow,E.T.: Effects of chromium on DNA replication in vitro. Environ Health Persp 102(3), 41 (1994).

156. Wilborn,F., Brendel,M.: Formation and stability of interstrand cross-links induced by cis- and transdiamminedichloroplatinum (II) in the DNA of Saccharomyces cerevisiae strains differing in repair capacity. Curr Genet 16, 331 (1989). 
157. Bridgewater,L.C., Manning, F.C.R., Patierno,S.R.: Base-specific arrests of in vitro DNA replication by carcinogenic chromium: relationship to DNA interstrand cross-linking. Carcinogenesis 15(11), 2421 (1994).

158. Kortenkamp,A., Curran,B., O'Brien,P.: Defining conditions for the efficient in vitro cross-linking of proteins to DNA by chromium(III) compounds. Carcinogenesis 13(2), 307 (1992).

159. De Flora,S., Bagnasco,M., Serra,D., Zanacchi,P.: Genotoxicity of chromium compounds. A review. Mutat Res 238, 99 (1990).

160. Kortenkamp,A., O'Brien,P.: The generation of DNA single strand breaks during the reduction of chromate by ascorbic acid and/or glutathione in vitro. Environ Health Persp 102(3), 237 (1994).

161. Tsuzuki,K., Sugiyama,M., Haramaki,N.: DNA single-strand breaks and cytotoxicity induced by chromate(VI), cadmium(II) and mercury(II) in hydrogen peroxide-resistant cell lines. Environmental Health Perspectives 102, 341 (1994).

162. Bridgewater,L.C., Manning,F.C.R., Woo,E.S., Patierno,S.: DNA polymerase arrest by adducted trivalent chromium. Mol Carcinogen 9, 122 (1994).

163. Borges,K.M., Wetterhahn,K.E.: Chromium bound to DNA alters cleavage by restriction endonucleases. Chem Res Toxicol 4(6), 638 (1991).

164. Tsou,T., Chen,C., Liu,T., Yang,J.: Induction of 8-hydroxydeoxyguanosine in DNA by chromium(III) plus hydrogen peroxide and its prevention by scavengers. Carcinogenesis 17(1), 103 (1996).

165. Tsou,T., Yang,J.: Formation of reactive oxygen species and DNA strand breakage during interaction of chromium(III) and hydrogen peroxide in vitro: evidence for a chromium(III)-mediated Fenton-like reaction. Chem-Biol Interact 102, 133 (1996).

166. Lloyd,D.R., Phillips,D.H., Carmichael,P.L.: Generation of putative intrastrand cross-links and strand breaks in DNA by transition metal ion-mediated oxygen radical attack. Chem Res Toxicol 10(4), 393 (1997).

167. Rodriguez,H., Holmquist,G.P., D'Agostino,R., Keller,J., Akmann,S.A.: Metal ion-dependent hydrogen peroxide-induced DNA damage is more sequence specific than metal specific. Cancer Res 57, 2394 (1997).

168. Alcedo,A.A., Misra,M., Hamilton,J.W., Wetterhahn,K.E.: The genotoxic chromium(VI) alters the metal-inducible expression but not basal expression of the metallothionein gene in vivo. Carcinogenesis 15(5), 1089 (1994)

169. Egilsson,V., Evans,I.H., Wilkie,D.: Toxic and mutagenic effects of carcinogens on the mitochondria of Saccharomyces cerevisiae. Mol Gen Genet 174, 39 (1979).

170. Kharab,P., Singh,I.: Induction of respiratory deficiency in yeast by salts of chromium arsenic cobalt and lead. Indian J Exp Biol 25(2), 141 (1987).

171. Singh,I.: Induction of reverse mutation and mitotic gene conversion by some metal compounds in Saccharomyces cerevisiae. Mutat Res 117, 149 (1983).

172. Steinkamp-Zucht,A., Fahrig,R.: Monitoring of induced chromosomal aberrations in S. cerevisiae in agarose gels by pulsed field electrophoresis. Mutat Res, 335, 285 (1995).

173. Ehlers,J., Tosch,M., AlBaz,I., Lochmann,E.R.: Rapid estimation of chromosomal damage in yeast due to the effects of environmental chemicals using pulsed field gel electrophoresis. Ecotox Environ Safe 22, 133 (1991).

174. Blöcher,D., Einspenner,M., Zajackowski,J.: CHEF electrophoresis, a sensitive technique for the determination of DNA double-strand breaks. Int J Radiat Biol 56(4), 437 (1989). 
175. Režić-Dereani,V., Raspor,P.: Evidence of chromium (VI)-induced DNA DSB in Saccharomyces cerevisiae yeast by PFGE. Period Biol 100(suppl. 1), 40 (1998).

176. Režić-Dereani,V.: Influence of Chromium Compounds on the Genome of Saccharomyces cerevisiae Yeast. Master Thesis. University of Ljubljana, Biotechnical Faculty, Ljubljana, 1999. pp. 1-92.

177. Cheng,L., Liu, S., Dixon,K.: Analysis of repair and mutagenesis of chromium-induced DNA damage in yeast, mammalian cells, and transgenic mice. Environ Health Perspect 106(4), 1027 (1998).

178. Dixon,K., Liu,S., Sonntag,D., Cheng,L: Chromium mutagenesis in yeast mammalian cells and transgenic mice. In 29th Annual Meeting of the Environmental Mutagen Society, Anaheim, California, USA, March 21-26, 1998. Environ Mol Mutagen 31(Supl. 29), 8 (1998). 